\title{
RISK ASSESSMENT IN TOURISM SYSTEM USING A FUZZY SET AND DOMINANCE-BASED ROUGH SET
}

\author{
Hassanali FARAJI SABOKBAR ${ }^{\mathrm{a}}$, Athareh AYASHI ${ }^{\mathrm{b}}$, Ali HOSSEINI ${ }^{\mathrm{c}}$, \\ Audrius BANAITIS ${ }^{\mathrm{d}}$, Nerija BANAITIENE ${ }^{\mathrm{d}}$, Raziyeh AYASHI ${ }^{\mathrm{e}}$ \\ ${ }^{a}$ Department of Human Geography, University of Tehran, Tehran 1417854151, Iran \\ ${ }^{b}$ Department of Tourism Planning, University of Tehran, Tehran 1417854151, Iran \\ ${ }^{c}$ Department of Geography and Urban Planning, University of Tehran, Tehran 1417854151, Iran \\ ${ }^{d}$ Department of Construction Economics and Property Management, Faculty of Civil Engineering, \\ Vilnius Gediminas Technical University, Sauletekio al. 11, 10223 Vilnius, Lithuania \\ ${ }^{e}$ Department of Tourism Planning, Kharazmi University, Tehran, Iran
}

Received 08 September 2015; accepted 06 February 2016

\begin{abstract}
The purpose of this study is to identify risks, discover rule base structure and the impact of risks by knowledge base system design in one of the Iran tourism destination. Based on tourism system approach, the factors of risks are divided in two dimensions: internal risks and external risks and seven criteria: political, economic, cultural-social, technological, environmental-health, functional and safe-security. Data were analyzed by fuzzy inference system and Dominance-based Rough Set Approach (DRSA) synthesizing to construction of forecasting risk assessment system. Tourists' perspectives towards the possibilities of risks were first assessed within seven risk factors and converted into a systematic structure within the structure of rough sets. Designing of a fuzzy expert system was dealt with using the created knowledge database. Then, the system's sensitivity analysis was examined. The results indicate that the system can be a good way to estimate the risks and their fluctuation rates and impacts on the development of tourism destinations. The technological, social, functional and safety-security risks had the highest values in the system designed for minimum travel repeatability. The research suggests that it is important impact of risks and their interaction with each other on the future development of tourism destination.
\end{abstract}

Keywords: tourism risk, risk assessment, dominance-based rough set approach (DRSA), Fuzzy Inference Systems (FIS), fuzzy set theory.

JEL Classification: C18, C44, C61, C81, O21, R11, R58, Z32.

Corresponding author Audrius Banaitis

E-mail: audrius.banaitis@vgtu.lt 


\section{Introduction}

In general, many ideas and perspectives have been generated for tourism models and definitions that included the interrelationship elements and components (Leiper 1979; Getz 1986; Jafari, Ritchie 1981). Therefore, tourism was considered as a systematic approach (Leiper 1979; Gunn, Var 2002; Glaesser 2006; Hall 2007; Goeldner, Ritchie 2009) and was introduced as an open system that divided internal and external environments (Ritchie 2009; Leiper 1979; Spanoudis 1982; Smith 1988).

Systematic approach to tourism has been proposed since 1990s by some scholars. Gunn, Var (2002) argues that tourism should be regarded as a system and states that whole tourism segments are related. The interaction, collaboration, performance and success of the various elements of the system lead to dynamics of tourism.

Goeldner and Ritchie (2009) notes that tourism is a system with centrality of tourists that it enveloped by natural resources and environment, operating sectors, strategies and policies factors. This study's approach is based on a combination of Hinch and Butler (1996) and Kaspar (1991) of tourism system. Kaspar (1989) discussed tourism system model is an open system. This system consists of internal structures such as theme and secondary subsubsystems associated with a superior system of social, economic, political, technological, and environmental atmospheres (Fig. 1). Butler's system theory is full-fledged of Leiper's system (1979) which consist of three elements: tourist generating regions, tourist destination regions and transit routes. Their tourism system model presented a framework for indigenous tourism that cross-cultural interactions factor is highlighted and has central role. The indigenous tourism system - as an open system - is impacted by environmental contexts in the economic, social, political and physical factors (Butler, Hinch 2007).

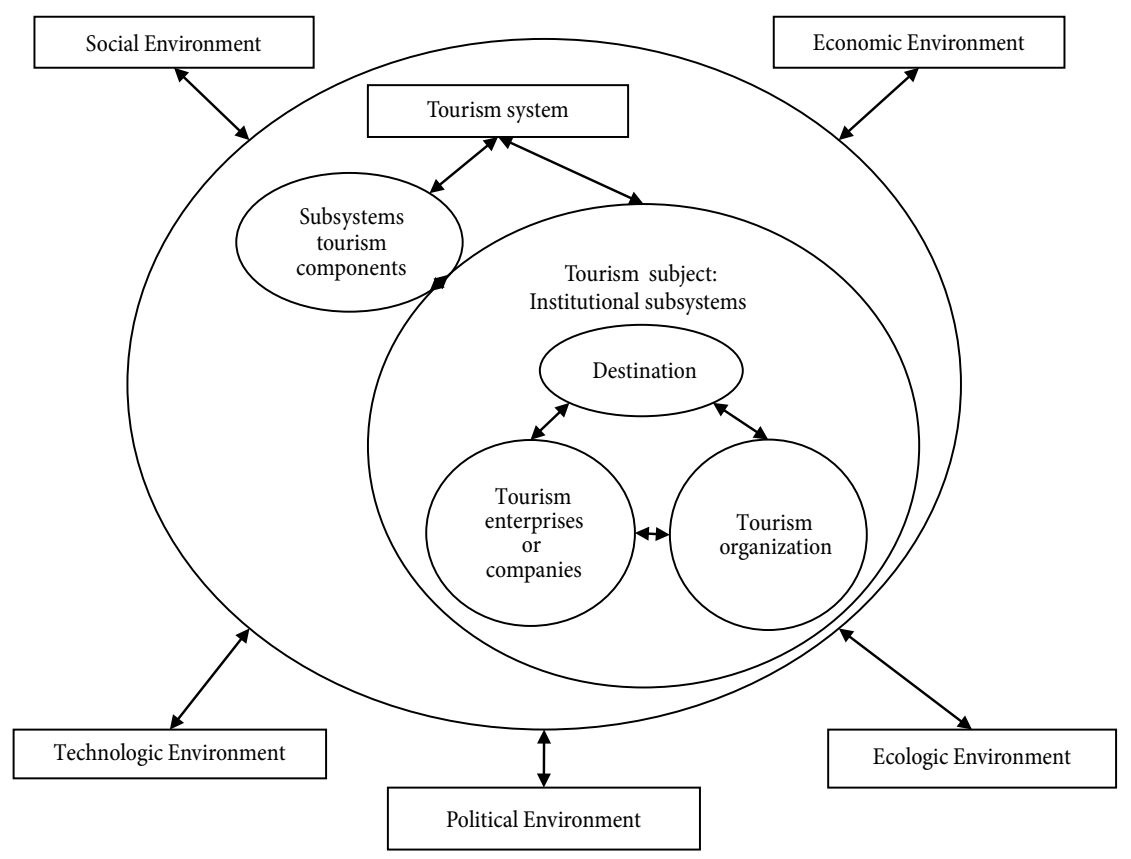

Fig. 1. Kaspar (1989) tourism system 
The literature suggested that tourism has proposed as an open system in which disasters and events can disturb internal structure and unsustainability of tourism system (Ritchie 2009; Sönmez, Graefe 1998; Kemp 2009).

The impact of risks increase with the rapid tourism development (Law 2006; Peattie et al. 2005; Kennedy 1998). In fact, each tourism destinations are exposed to events and negative factors that can be able to disaster tourism destination system such as unpleasant and inedible foods, inappropriate destination's accommodations, theft, fatality, bad weather, unfriendly locals, plane crash, terrorism, crime, unrest political, disease and natural disaster. These factors impact in tourism components and tourists (Fuchs, Reichel 2006; Bentley, Page 2008; Fuchs, Reichel 2011). Therefore, the negative events are considered as risks that have potential to severely damage and cause to loss tourism structure (Tsai, Chen 2011; Bentley, Page 2008). In this paper, we would identify risks, discover rule base structure and the impact of risks by knowledge base system design in one of the Iran tourism destination.

\section{Literature review}

In this section, the literature related to tourism risk and risk assessment is surveyed.

\subsection{Tourism risk}

Tourism system is the complex, dynamic and multi - dimensional (Inskeep 1991), so that it is not coherent and integrated (Sessa 1988). Also, the main properties of tourism are vogue and uncertain that occur in possibility and uncertainty environments (Hsu, Lin 2006). These components are interacting with each other. Hence, we should say that the systems would meet a range of risks affecting their performances and objectives at every level in every time and place (Hongxia et al. 2012). According to previous studies, tourism risks have identified and categorized such as: physical risks refer to physical injuries to consumers and show the functional of products; economic risks related to the money invested, which will be lost through the products, structural and functional risks consisting of the risks of the products identified with the probabilities that will not run as expected, the social risks of the fear of noncompliance of the purchases with the reference group standards, the psychological risks of the fear of incompatibility of the products with the buyers' imaginations, and the time risks of the probability of the excessive time-consuming consumption of the products (Sönmez, Graefe 1998; Simpson, Siguaw 2008; Quintal et al. 2010; Fuchs, Reichel 2006, 2011). Moreover, some researchers in the field of tourism have mentioned health risks, terrorism, crimes, and political instabilities (Sönmez, Graefe 1998; Peattie et al. 2005; Lepp, Gibson 2003; Simpson, Siguaw 2008).

Tsaur et al. (1997) investigated tourist risk and cover them in two main types: physical risk and equipment risk that divided seven objectives including transportation, law and order, hygiene, accommodation, weather, sightseeing spot and medical support and 16 risk evaluation attributes, such as safety of transportation, convenience of telecommunication facilities, safety of driving, political stability, possibility of criminal attack, attitude of inhabitants towards tourist, possibility of contracting infectious disease, hygiene of catering 
conditions, hotel fire control system, hotel security system, difference of weather change, possibility of natural disasters, safety of recreational facilities, quality of the management staff, degree of assistance available in case of accident, completeness of medical service system. This study applied AHP to weight objectives and chose six representative group package tour itineraries with 20 persons for Taiwanese groups. Also, fuzzy method was used to classify evaluation of tourist risks. The results indicated the comparative importance of criteria. It pointed out that law and order, transportation and hygiene are the most important aspects in evaluation risk. As possibility, criminal attack and political stability and contracting infectious diseases are the most important criteria. Itinerary of Japan perceived the least risk and Itinerary of Gorges and China revealed the highest risk.

Simpson and Siguaw (2008) focused on risk perception and identifies the relative importance of risk types by the number of tourists. The authors determined travel risks in five traditional risk categories and the data analysis resulted in the 10 travel risk categories. The list of travel risks to manage can be divided in controllable, manageable, uncontrollable and unmanageable. In this study, it was examined the significance of relationships between the various factors and demographic characteristics. The study indicated that physical, performance risks with health and well-being and travel destination environment are most dominant. Also, it was found that criminal harm, travel service provider performance, travel and destination environment and concern about others were controllable risks. In addition, uncontrollable risks were health and well-being, transportation performance, generalized fears, monetary concerns and concern for others. Hsu and Lin (2006) have developed a framework for subjective cognition on tourism risk attitude. They noted that tourists perceived uncertainty in purchasing travel related products. Travel perceived risk were classified into six parts - financial, physical, psychology, social, time and functional risks - which developed in 44 questions. They used two factors of risk management - possibility of occurrence and seriousness of occurrence - and fuzzy multi-criteria method to analysis perceived-risk and construct the risk matrix. Using this matrix were indicated which risk attribute had higher sensitivity and uncertainty. They found that financial and physical risk had a greater occurrence and the seriousness of occurrence is very high and the consumers believed that time risk items are unlikely to happen. Eitzinger and Wiedmenn (2007) have explored the perceived risks in Alpine, Austria tourist destination. There are two main object in this study: what kind of risks are there in Tyrol area and what is probable occurrence of the risks. The results show that identification and determination of risks is one of the best solution to perceived risk. Also, it is indicated that attribution of tourists towards to risks depends on seriousness of occurrence. So, it is necessary to investigate the influence factors and variables of the system otherwise it occurs risks (Hongxia et al. 2012) and risk management can applied to whole systems which the main purpose of it is identify and assess risks (Zhiwei, Zhongyuan 2012; Hongxia et al. 2012). Although it could not eliminate the whole risks but also it must manage to reduce vulnerability (Ritchie 2009). Tourism system follows this trend. Hence, in this study has been concerned by system risk management approach to tourism risk assessment. 


\subsection{Risk assessment}

Risk is a common phenomenon and every person is faced and influenced by risk factors. Risk is defined in ISO 31000 - risk management - as "effect of uncertainty on object" such as organizations and systems. According to ISO 31000 and previous studies (Perera, Holsomback 2005; Liu, Zhai 2008; Ye, Wen 2009) risk assessment contain three main components: risk identification, risk analysis and risk evaluation.

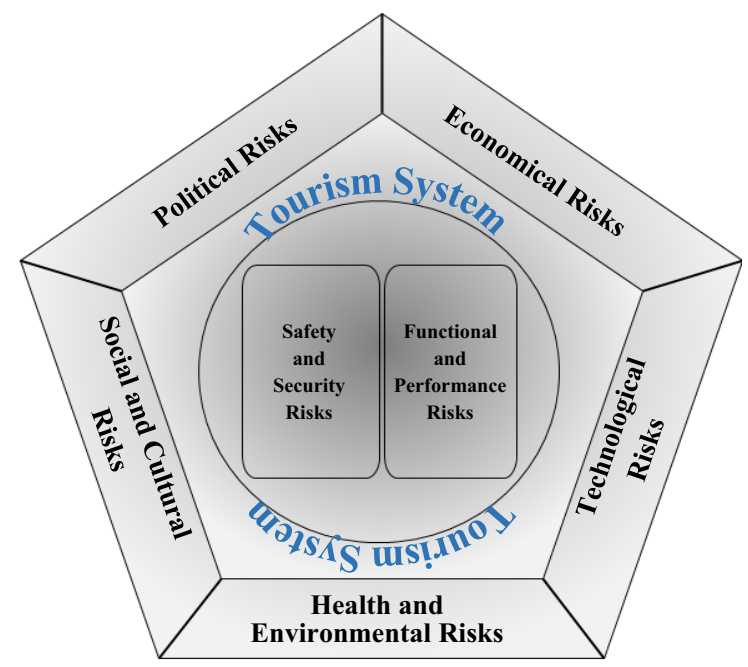

Fig. 2. Dimensions and components consolidated of risk management approach with tourism system theory in destinations

Based on Yates (1992) there are three elements for risk criteria: 1) potential of losses, 2) the significance of losses, 3) the uncertainty of losses. Therefore, risk refers to the negative effects or damages that would lead to potential risks or extreme events. It can be defined by two main elements: a. probability, b. consequences (Perera, Holsomback 2005; Ye et al. 2010; Aven 2011). It is indicated that risks are multidimensional subject (Pizam et al. 2004; Assmuth et al. 2010).

In this study risk management as a principle approach has consolidated with tourism system theory in destinations to denote risk dimensions and components (Fig. 2).

\section{Methodology}

\subsection{Dominance-based Rough Set Approach (DRSA)}

The rough set theory is a rule-based approach to uncertain information developed by Pawlak in two famous works (Pawlak 1982, 1991). The fundamental concept behind rough set theory is the approximation of lower and upper spaces of a set, the approximation of spaces being the formal classification of knowledge regarding the interest domain. The original rough set approach is not able, however, to deal with preference-ordered attribute 
domains and decision classes (Greco et al. 2001; Błaszczyński et al. 2007, 2012; Słowiński et al. 2007; Shen, Tzeng 2015). So, Greco et al. (1999, 2001, 2002, 2005) have proposed an extension of the rough sets approach, called Dominance-based Rough Set Approach (DRSA). DRSA is able to deal with sorting problems involving criteria. This innovation is mainly based on substitution of the indiscernibility relation by a dominance relation in the rough approximation of decision classes. Decision rules with a special syntax are further induced from these approximations of decision classes. The calculation of DRSA can be summarized as follow as:

\section{Determination of the criteria and decision matrix}

Decision matrix is an information system that include a finite universe of objects $(U)$ evaluated on a finite set of condition attributes $F=\{f 1, \ldots, f n\}$. In decision matrix, the rows correspond to decision objects and columns correspond to attributes that the input data are the attribute value. The two factors are used in decision rules. Therefore decision matrix have four-tuple consisting a finite universal set, a finite set of attributes, finite set as a domain of attributes and an information function (Eq. (1)).

$$
S=\{U, Q, V, F\},
$$

where: $U$ is a finite set of objects, $Q$ is a finite set of attributes, $V=U q \in Q V q$, where a $V q$ is a domain of the attributes, $F: U \times Q, \rightarrow V$ is a function called an information function $f(x, q)=q(x) \in V q$ for every $q \in Q$ and $x \in U$.

The main idea of rough set is approximation of knowledge by another knowledge. Analyzing by DRSA is performed to be approximated are called upward and downward unions of classes.

If $x$ dominates $y$ with respect to $P \subseteq C$, denoted by $x D p y$, If $x$ is better than $y$ on every criterion from $P, P, x \succeq_{q} y, q \in P$. Given $P \subseteq$ and $x \in U$, the "granul of knowledge" used for approximation are:

A set of objects dominating $x$, called $p$-dominating set (Eq. (2)),

$$
D p+(x)=\{y \in U: y D p x\} .
$$

A set of objects dominated by $x$, called $p$-dominated set (Eq. (3)),

$$
D p-(x)=\{y \in U: x D p y\} \text {. }
$$

\section{Rough approximation}

The $p$-lower approximation of $\geq t$, denoted as $P(C l \geq t)$ and the $p$-upper of $C l \geq t$ denoted as $P(C l \geq t)$, are defined as Eqs (4) and (5):

$$
\begin{gathered}
P(C l \geq t)=\{x \in U: D+P(x) \subseteq C l \geq t\} ; \\
P(C l \geq t)=\{x \in U: D-P(x) \cap C l \geq t \neq \Phi\} .
\end{gathered}
$$

The P-boundaries of $C l \geq t$ and $C l \leq t$ are defined as $B n p(C l \geq t)$ and $B n p(C l \leq t)$ follow as Eqs (6) and (7):

$$
\begin{aligned}
& B n p(C l \geq t)=P(C l \geq t)-P(C l \geq t) \\
& B n p(C l \leq t)=P(C l \leq t)-P(C l \leq t) .
\end{aligned}
$$




\section{Quality of approximation}

For every $P \subseteq C$, quality of approximation of the ordinal classification $C l$ by a set of attribute $P$ is defined as the ratio of the number objects $p$-consistent with the dominance base. While $p$-consistent objects that don't belong to any $p$-boundary, $(C l \geq t), t=2, \ldots, m$ or $\operatorname{Bnp}(C l \leq t), t=1, \ldots, m-1$.

Quality of approximation by a set of attributes $P$, can be calculate as Eqs (8) and (9):

$$
\alpha p\left(C l_{t}^{\geq}\right)=\frac{\left|\underline{P}\left(C l_{t}^{\geq}\right)\right|}{\left|\bar{P}\left(C l_{t}^{\geq}\right)\right|}, \alpha p\left(C l_{t}^{\leq}\right)=\frac{\left|\underline{P}\left(C l_{t}^{\leq}\right)\right|}{\left|\bar{P}\left(C l_{t}^{\leq}\right)\right|} .
$$

The ratio:

$$
\gamma p(C l)=\frac{\mid U-\left(U_{t=2, \ldots, n} B n_{p}\left(C l_{t}^{\geq}\right) \mid\right.}{|U|}=\frac{\mid U-\left(U_{t=1, \ldots, n-1} B n_{p}\left(C l_{t}^{\leq}\right) \mid\right.}{|U|} .
$$

\section{Reduction of attributes}

Every minimal subset $P \subseteq C$ such that $\gamma p(C l)=\gamma c(C l)$ is called a reduct of $C l$ and is denoted by $R E D_{c l}(P)$. A decision matrix may have more than one reduct.

\section{Decision rules}

In fact, decision rules express by two parts, If (condition), Then (decision) that indicate dependency between condition criteria and decision criteria. Therefore, there are three types of rules: certain, possible and approximate. For a given upward and downward union classes, $\mathrm{Cl} \geq t$ or $\mathrm{Cl} \leq t$ the decision rules extract under a hypothesis that objects belonging to $P(C l \geq t)$ or $P(C l \leq t)$.

\subsection{Fuzzy theory}

Fuzzy Inference Systems (FIS) are popular computational frameworks and based on the concept of fuzzy sets. FISs are nonlinear systems designed of solve decision making and inference problems in uncertainty and assessment condition according to the rules that connect the input and output variables defined as If-Then (Baraldi et al. 2009).

The basic structures of FIS are composed of five conceptual parts (Haji, Assadi 2009):

1. Identification of the input and output variables and definition of appropriate linguistic variables of fuzzy sets for each variable.

2. Definition of the membership functions of fuzzy sets used in the rules.

3. Definition of knowledge database on the basis of If-Then rules.

4. Running of the inference rules on the rules.

5. Defuzzification which converts the inference results into real numbers.

\subsubsection{Determination of fuzzy expert system structure}

In this study, to fuzzyficate the inputs, linguistic values were considered for the criteria and their membership functions. Then, to form a knowledge database, knowledge engineering was performed in a way that the discovery of knowledge was done using rough set approach. As a result of which, expert system rules were created. The next step was to 
determine the inference type of fuzzy expert system. An expert system is based on a set of If-Then rules. An optimal reasoning method would be to first infer the individual rules and then merge the results named First Infer Then Aggregate (FITA). Of all the reasoning methods of FITA, Mamdani inference method is very common and popular (Susniene, Purvinis 2015), which was used in this survey.

The research model of fuzzy expert system was of Multiple Inputs-Single Output (MISO) type that can be converted into a set of rules as the following relation:

Step 1. Determine structure of fuzzy expert system

$$
R_{i}=\text { If } X 1 \text { is } A_{i} 1 \text { AND } X 2 \text { is } A_{i} 2 \text { AND } \ldots X_{j} \text { is } A_{i j} \text { Then } y \text { is } B_{i}, i-1, \ldots, n \text {, }
$$

where: $R_{i}$ indicates $i$ th rule, $X_{j}$ is the number of input variables, $y$ is the only output variable of the system, $A_{i j}$ is the inputs of fuzzy sets defined as $U=u 1, \ldots, u r$ in the reference set environment, and $B_{i}$ is the outputs of fuzzy sets defined as $V$ in the reference set.

Therefore, each rule is a local fuzzy relationship between $U^{\star} V$, which maps a part of the multidimensional input space of $U$ into a specific part of $V$ output space. As evident from the above relation, the relationship between all the entities in this study is AND. Integration of the rules of the above relation constitutes the laws of the system presented as the following Eq. (11):

$$
R=\bigcup_{i=1}^{n} R_{i}=\mathrm{R} 1 \text { ALSO R2 ALSO, ,.., ALSO Rn. }
$$

The output values obtained were in fuzzy form and to simplify and analyze them, the fuzzy numbers were defuziated using the center of gravity method and converted into ordinary numbers (Najjaran et al. 2006).

Step 2. Determination of the criteria values for risk assessment

The first stage of processing fuzzy expert systems is fuzziation of the input and output variables of the system (Matthews 2003; Siler, Buckley 2005). To obtain a single value for the risk qualitative components, the verbal variables have to be converted to triangular fuzzy numbers to be calculated and analyzed.

\subsubsection{The definition of linguistic variables and fuzzy sets}

At this stage, according to the previous studies (Hsu, Lin 2006; Tsaur et al. 1997) and experts' opinions, linguistic fuzzy interval of the fuzzy set and its membership function for the input -possibilities of risk components - (Table 1 and Fig. 3) and output - level of satisfaction from the trip - (Table 2 and Fig. 4) parameters were determined.

Table 1. Linguistic variable of risk dimensions

\begin{tabular}{lccc}
\hline & Value of linguistic & Verbal values & Fuzzy range \\
\cline { 2 - 4 } Input variables - risk factors & $\mathrm{A}<2$ & Low risk & $1-2.5$ \\
\cline { 2 - 4 } & $2 \leq \mathrm{A} \leq 4$ & Moderate risk & $1.5-4.5$ \\
\cline { 2 - 4 } & $\mathrm{A} \geq 4$ & High risk & $3.5-5$ \\
\hline
\end{tabular}




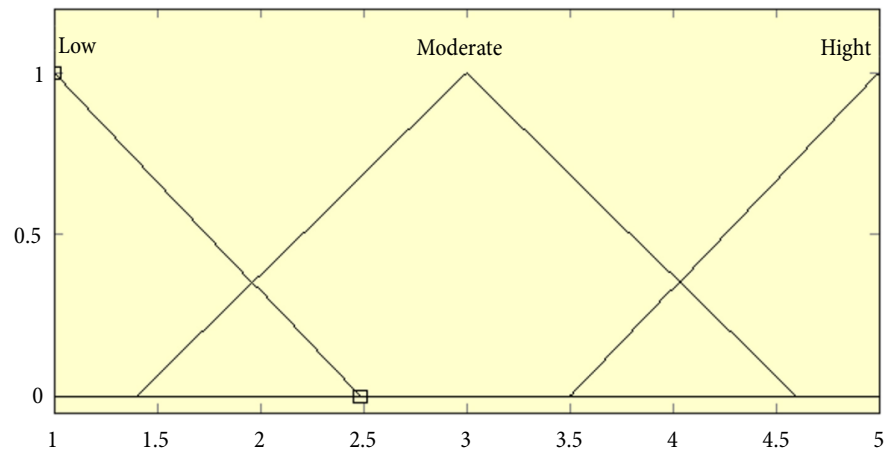

Fig. 3. Membership function of risk dimensions

Table 2. Linguistic variable of satisfaction

\begin{tabular}{cccc}
\hline & Value of linguistic & Verbal values & Fuzzy range \\
\cline { 2 - 4 } Output variable - satisfaction tourists & $\mathrm{A}<0.1$ & $\mathrm{~B}$ & $0-0.2$ \\
\cline { 2 - 4 } & $0.1 \leq \mathrm{A} \leq 0.3$ & Not $\mathrm{Bad}$ & $0-0.4$ \\
\cline { 2 - 4 } & $0.3 \leq \mathrm{A} \leq 0.5$ & Moderate & $0.2-0.6$ \\
\cline { 2 - 4 } & $0.5 \leq \mathrm{A} \leq 0.7$ & Not good & $0.4-0.8$ \\
\cline { 2 - 4 } & $0.7 \leq \mathrm{A} \leq 0.9$ & Good & $0.6-1$ \\
\cline { 2 - 4 } & $\mathrm{A} \geq 0.9$ & Excellent & $0.8-1$ \\
\hline
\end{tabular}

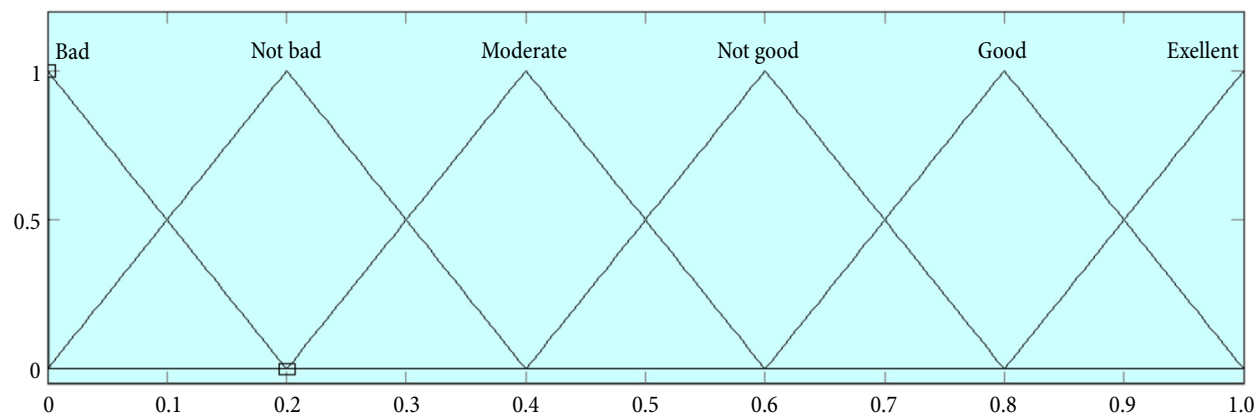

Fig. 4. Membership function of satisfaction

\subsubsection{Knowledge-based system and fuzzy rules}

In the present study, fuzzy expert system rules were based on rough sets. Rough set theory is a mathematical tool which is able to account for uncertainty and ambiguity. Rough set theory emphasizes on the discovery of particular patterns in the incomplete data obtained from intelligence sources. It can be a basis for the detailed reasoning with uncertain information. 


\section{Empirical tourism risk study in Iran}

Khoram Abad is $4936 \mathrm{~km}^{2}$ in $47^{\circ}$ and $41^{\prime}$ and $48^{\circ}$ and $57^{\prime}$ of east and $32^{\circ} 56^{\prime}$ and $33^{\circ} 51^{\prime}$ of north. It is one of cities of Lorestan province. As this city has sweet valley weather and roaring springs among high mountains, it has interesting sight in nature. Enriched culture of Khoram Abad is seen in city, rural and especially in tribal areas. Due to geo-political and social factors, actual and potential natural resources of this area are interesting for foreign tourists including walkways and jungles of this province. But it is not considered by domestic and foreign tourists widely.

Khoram Abad has three main specifications as follows:

- Khoram Abad, as center of Lorestan province and a part of Zagros region, has lots of valuable natural sources that are considered as important national sources.

- Khoram Abad and Lorestan province is one of the main focus and sources of occurrence and persistence of Iranian civilization. Protection and restoring identity and monuments forms one of pillars of sustainable development at the national level.

- Khoram Abad is origin and residence of Lor race which is one of main Iranian race. In anthropology view, language and culture of nomads people is very valuable.

Also, due to the lack of attractions for tourists, inappropriateness of tourist facilities, thus resulting in an insecure environment for them, environmental pollutions, planning and executing problems, and unfamiliarity of the indigenous and the host community with affairs related to tourism, the tourism development system of this township is vulnerable to risk.

\subsection{Data collection}

\subsubsection{Delphi method}

After literature review we used Delphi method for determining of risk criteria. The Delphi method begins with the development of a survey (Ferreira et al. 2015). This method is based on the assumption that group judgements are more valid than individual judgements (Maknickienè, Maknickas 2013; Lin, Pan 2014; Tan et al. 2014; Razavi Hajiagha et al. 2015). In the present study, snowball technique was used to determine the group of experts. In the process of collecting the questionnaires, experts were divided into two groups: Group A included five experts of the subject from the Cultural Heritage, Handcrafts and Tourism Organization of Lorestan, four experts from the Environment Organization, six hotel managers and employers, five tour and travel agencies managers, five from the First Aid Organization; Group B included academic experts.

\subsubsection{Survey data}

After literature review, two dimensions were considered for tourism risk system: internal and external risks. Criteria were classified in the two parts based on the model of last section. Research criteria were identified based on Delphi questionnaire in two rounds. The results of the first round questionnaires were collected. 64 indexes were localized for factors and contexts of tourism risk. The Likert scale was used for the second round question- 
naires. Finally, 17 criteria and 33 indicators were identified. External risk context included political risks, economic risks, social-cultural risks, environmental and health risks, technological risks. Internal context risk includes operational risks, safety and security. Results of the second round questionnaires is presented in Table 3.

Table 3. Dimensions, components, criteria and indicators for tourism risks systems

\begin{tabular}{|c|c|c|c|}
\hline Dimensions & Components & Criteria & Indicators \\
\hline \multirow[t]{19}{*}{$\begin{array}{l}\text { External } \\
\text { context risk }\end{array}$} & \multirow[t]{3}{*}{ Political (C1) } & $\begin{array}{l}\text { Government } \\
\text { policies }\end{array}$ & Macro advertisements by the government \\
\hline & & Law and Rules & The absence of laws in attractions area \\
\hline & & Political situation & Volatility tourism decision making \\
\hline & \multirow[t]{3}{*}{ Economic (C2) } & \multirow[t]{2}{*}{ Prices } & Inflation \\
\hline & & & Unknown price of tourism services \\
\hline & & Financial oncerns & Expensive services \\
\hline & \multirow{7}{*}{$\begin{array}{l}\text { Socio-Cultural } \\
\text { (C3) }\end{array}$} & \multirow[t]{3}{*}{ Crime } & Violence against tourists \\
\hline & & & $\begin{array}{l}\text { Encounter indigenous people and tourist and } \\
\text { extorting }\end{array}$ \\
\hline & & & Theft \\
\hline & & \multirow[t]{2}{*}{$\begin{array}{l}\text { Socio-cultural } \\
\text { conflict }\end{array}$} & $\begin{array}{l}\text { Lack of hospitality knowledge in local } \\
\text { communities }\end{array}$ \\
\hline & & & Lack of participation of local residents \\
\hline & & \multirow{2}{*}{$\begin{array}{l}\text { Psychological } \\
\text { threats }\end{array}$} & Negative tourists imagination \\
\hline & & & Experience and satisfied feeling \\
\hline & \multirow{3}{*}{$\begin{array}{l}\text { Environmental } \\
\text { and Health } \\
\text { (C4) }\end{array}$} & \multirow{2}{*}{$\begin{array}{l}\text { Environmental } \\
\text { Health }\end{array}$} & pollutants weather \\
\hline & & & Hygiene and clean environment. \\
\hline & & biology & Disease \\
\hline & \multirow{3}{*}{$\begin{array}{l}\text { Technological } \\
\text { (C5) }\end{array}$} & \multirow{2}{*}{$\begin{array}{l}\text { Failure of tourism } \\
\text { facilities }\end{array}$} & Bank systems weakness \\
\hline & & & $\begin{array}{l}\text { Accommodation services and tourism } \\
\text { infrastructure weaknesses }\end{array}$ \\
\hline & & $\begin{array}{l}\text { Transport system } \\
\text { failure }\end{array}$ & $\begin{array}{l}\text { Lack of modern transportation with new } \\
\text { technologies }\end{array}$ \\
\hline \multirow{14}{*}{$\begin{array}{l}\text { Internal } \\
\text { context risk }\end{array}$} & \multirow{9}{*}{$\begin{array}{l}\text { Functional } \\
\text { (C6) }\end{array}$} & \multirow{5}{*}{$\begin{array}{l}\text { Management and } \\
\text { planning risk }\end{array}$} & Making decisions and staff performance \\
\hline & & & Non - professional travel agencies \\
\hline & & & Disorder in tours itineraries \\
\hline & & & Lack of bookkeeping tourism attraction \\
\hline & & & Improper maintenance and damage attractions \\
\hline & & \multirow{2}{*}{$\begin{array}{l}\text { Strategic Marketing } \\
\text { risk }\end{array}$} & Lack of proper advertising \\
\hline & & & $\begin{array}{l}\text { The lack of balance between supply and } \\
\text { demand in the market }\end{array}$ \\
\hline & & \multirow{2}{*}{$\begin{array}{l}\text { Human resources } \\
\text { risk }\end{array}$} & The unskilled and untrained human resources \\
\hline & & & $\begin{array}{l}\text { The lack of experienced tourist guides for } \\
\text { security }\end{array}$ \\
\hline & \multirow[t]{5}{*}{$\begin{array}{l}\text { Safety and } \\
\text { Security (7) }\end{array}$} & \multirow[t]{3}{*}{ Safety Equipment } & $\begin{array}{l}\text { Non-observance of safety standards in tourism } \\
\text { infrastructure such as residential centers }\end{array}$ \\
\hline & & & $\begin{array}{l}\text { The lack of network transport safety and road } \\
\text { accidents }\end{array}$ \\
\hline & & & $\begin{array}{l}\text { Lack of sanitation in restaurants and catering } \\
\text { complex }\end{array}$ \\
\hline & & \multirow[t]{2}{*}{ Physical security } & Insecurity in the area tourist attractions \\
\hline & & & Emergency and rescue \\
\hline
\end{tabular}


A questionnaire is designed for entrance tourists, based on specified indicators and items. The total number of the risk questions was 46 questions. Three questions for political risks, five questions for economic risks, nine questions for social-cultural risks, three questions for environmental-health risk, four questions for technology risks, fourteen questions for functional risks and seven questions for the safety and security risks (Table 1).

Moreover, one question examines a total idea of the respondent about the amount of satisfaction of tourist in this area. This answer is used for rule decision in DRSA. The questions, in the type of expressions, examine the probability of identified risks in tourist's views. Each question was measured by five point scale for the criterion from "very low" to "very much" (Table 2).

Statistical population includes arrival tourists and visitors of tourism attractions of Khoram Abad. Questionnaires were filled by tourists in the first 15 days of spring. Respondents were selected randomly. Then, two questioners filled 246 questionnaires in tourism attraction place including 80 women (32.5\%), and 166 men (67.5\%). Based on tourist type, respondents were as follows: Traveling was in the form of familial 117 (47.6\%), a group of friends 70 (28.5), tour 46 (18.7), daily tours 13 (5.3\%). Possible view of tourists towards to any kind of risk was asked based on linguistic variable of risk dimensions form (Table 1) and was used for discovering knowledge.

In order to design fuzzy inference system and to forecast tourism risks, it is needed to codify some rules. Rough sets were used to codify these rules. The obtained data were analyzed in JMAF software. Then, variables of research were defined in the fuzzy sets system. The obtained rules of DRSA were used in MATLAB as system training in FIS model. Also, to evaluate risks in tourist destination system, following steps are performed (Fig. 5):

1. Identifying the potential risks.

2. Risk analysis.

3. Risk assessment.

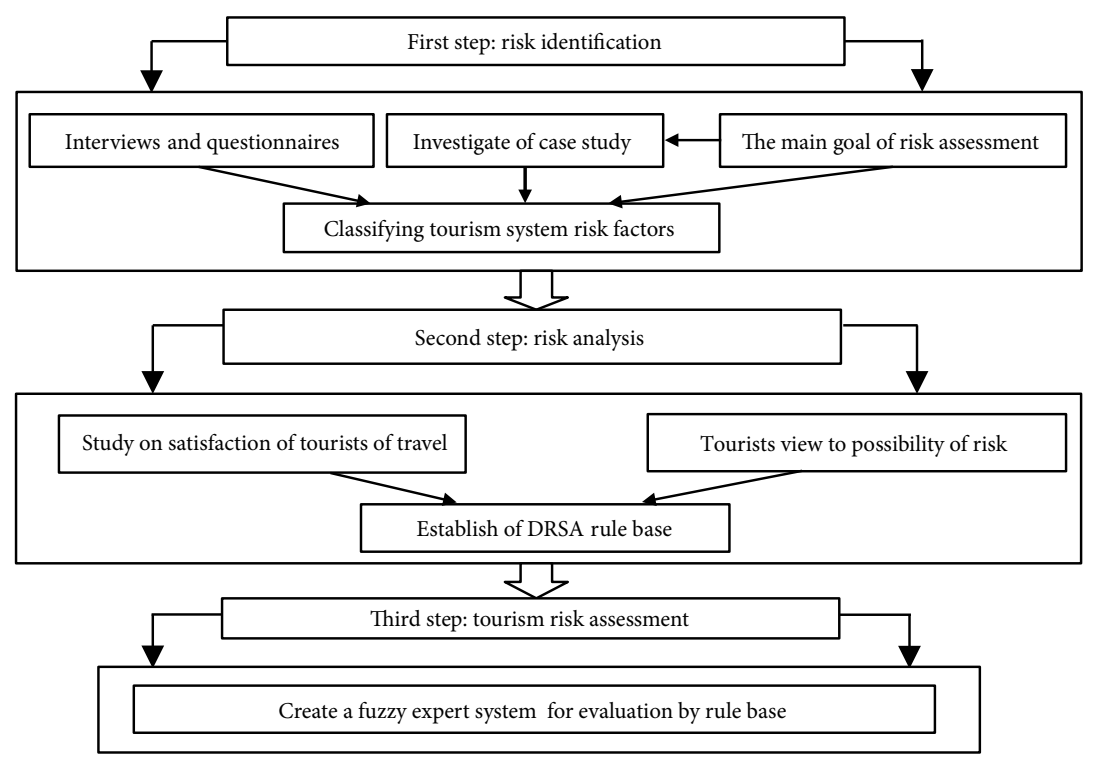

Fig. 5. Flowchart of proposed model to evaluate risks in tourist destination system 


\section{Results and discussion}

\subsection{Analysis of fuzzy expert system sensitivity for defining level of risk}

General approach of creating an expert system based on exploring knowledge with DRSA has been shown in Figure 6. For creating the system, data of a questionnaire about tourists' point of view on risk dimensions containing political, economic, social-cultural, technological, safety-security risks and functional risk have been used. After completing questionnaire by tourists based on research model, initially all questionnaires have been analyzed and combined with each other in SPSS. Afterwards, eight fields of risk criteria and tourist's satisfaction were imported in JMAF and risk decision matrix was created in order to analyze DRSA.

Decision matrix in this study was formed so that seven risk dimensions as condition attribute and tourist's satisfaction as decision attribute were specified. Value of risk dimensions were based on the Table 2. The results of this step are shown in Table 4.

After creating the decision matrix (Table 4), calculations of criteria and definition of their type were defined and stored in a data file. In Table 2, lower and upper approximates of decision field union set were calculated. In this calculation, amount of consistency level has been considered to be 0.5 . Quality of approximation also was calculated for data series which equals to 0.73 (Table 5).

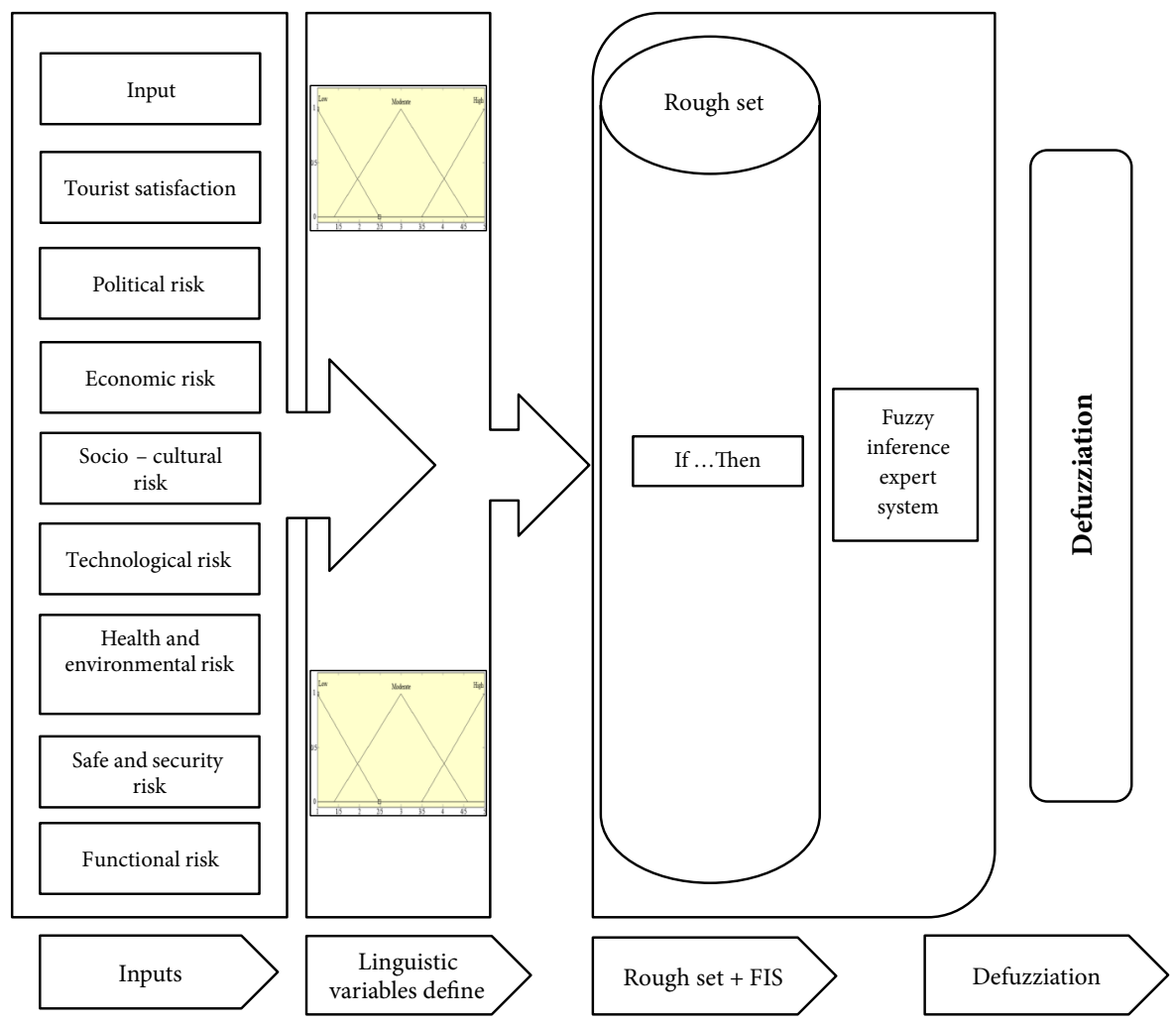

Fig. 6. Modeling and establishment of a system of knowledge risk-based tourism 
Table 4. Risk dimensions decision matrix

\begin{tabular}{ccccccccc}
\hline Object & C1 & C2 & C3 & C4 & C5 & C6 & C7 & Decision \\
\hline Q1 & 5 & 4 & 3 & 5 & 3 & 4 & 3 & 3 \\
\hline Q2 & 5 & 3 & 3 & 4 & 3 & 4 & 3 & 4 \\
\hline Q3 & 5 & 3 & 2 & 3 & 3 & 4 & 3 & 3 \\
\hline Q4 & 4 & 3 & 3 & 3 & 3 & 4 & 3 & 4 \\
\hline Q5 & 5 & 3 & 2 & 3 & 3 & 3 & 2 & 3 \\
\hline$\ldots$ & $\ldots$ & $\ldots$ & $\ldots$ & $\ldots$ & $\ldots$ & $\ldots$ & $\ldots$ & $\ldots$ \\
\hline Q246 & 4 & 4 & 3 & 4 & 5 & 4 & 4 & 4 \\
\hline
\end{tabular}

Table 5. Accuracies of approximation

\begin{tabular}{ccccccccc}
\hline Union & $\mathrm{Cl} \geq 1$ & $\mathrm{Cl} \leq 2$ & $\mathrm{Cl} \geq 2$ & $\mathrm{Cl} \leq 3$ & $\mathrm{Cl} \geq 3$ & $\mathrm{Cl} \leq 4$ & $\mathrm{Cl} \geq 4$ & $\mathrm{Cl} \leq 5$ \\
\hline Accuracy & 0.33 & 0.95 & 0.57 & 0.85 & 0.84 & 0.75 & 0.96 & 0.67 \\
\hline
\end{tabular}

Next step is calculation of rules. In this study 78 rules column have been made which are used as the knowledge data center for fuzzy inference system. For implementing fuzzy inference system, MATLAB was used. Then variations were defined and determined fuzzy value in system and the rules derived from DRSA were taught to system. Numbers of these rules after fuzzy variation extend to 1062 rules. Finally in order to analyze sensitivity of this expert system, filling of 10 new questionnaires from tourists perceive towards to risk possibility is considered as a tester. Consequently, questions of each criteria were combined with each other and assessed in the system.

According to achieved results from fuzzy expert system for forecasting tourism risk it's revealed that, the higher and more risk leads to lower level of tourist's satisfaction and with less probability she/he would repeat this trip and vice versa. This system will able to forecast level of tourists'satisfaction and repeatability of their trip with gauging risk level and it's variation in each criteria. Achieved results from Table 6 of fuzzy expert system functionality are acceptable. So that it will changes decision field value with changing in risk factor levels. These changes are in accordance with the tourists perceives towards to risks and repeat the journey and there are relationship between changing dimensions and repeatability of trips as decision field. In these 10 experimental questionnaires, level of satisfaction was in the range of 0.320 to 0.615 . According to this system it is possible to minimize risk indexes for future programming in order to expect the most rate of repeating trip from tourists and to forecast positive advertisement for future tourists' imagine.

In this study, knowledge-based risk system for tourism destination of Khoram Abad with knowledge discovery from tourists' point of view was established and integrated system of DRSA and fuzzy multi-criteria were implemented for creating intelligence. Types of risk analyzed, were divided in two general groups of internal risks - functional and safety - and external risks - social - cultural, economic, political, environmental and health, technological - of tourism system. These risks according to what is said in context and regarding to case study were codified. The lowest level of satisfaction and willing to repeat the trip occur when there is highest level of risk inside of destination tourism system. 
Table 6. Sensitivity analysis of tester's opinions

\begin{tabular}{cccccccccccc}
\hline $\begin{array}{c}\text { Risk di- } \\
\text { mensions }\end{array}$ & Criteria & \multicolumn{10}{c}{ Values of test } \\
\hline \multirow{2}{*}{$\begin{array}{c}\text { External } \\
\text { risks }\end{array}$} & $\mathrm{C} 1$ & 1 & 4 & 2 & 3 & 1 & 1 & 2 & 4 & 3 & 1 \\
\cline { 2 - 14 } & $\mathrm{C} 2$ & 2 & 4 & 3 & 3 & 3 & 4 & 1 & 5 & 2 & 2 \\
\cline { 2 - 14 } & $\mathrm{C} 3$ & 3 & 5 & 4 & 5 & 5 & 3 & 2 & 5 & 3 & 4 \\
\cline { 2 - 13 } & $\mathrm{C} 4$ & 2 & 4 & 3 & 5 & 5 & 4 & 3 & 3 & 4 & 3 \\
\cline { 2 - 14 } & $\mathrm{C} 5$ & 2 & 5 & 3 & 5 & 4 & 4 & 3 & 4 & 1 & 5 \\
\hline \multirow{2}{*}{$\begin{array}{c}\text { Internal } \\
\text { risks }\end{array}$} & $\mathrm{C} 6$ & 2 & 5 & 3 & 1 & 1 & 5 & 3 & 3 & 3 & 2 \\
\cline { 2 - 13 } & $\mathrm{C} 7$ & 3 & 5 & 4 & 5 & 5 & 4 & 4 & 5 & 2 & 2 \\
\hline & Decision & 0.536 & 0.320 & 0.437 & 0.463 & 0.500 & 0.599 & 0.527 & 0.428 & 0.553 & 0.615 \\
\hline
\end{tabular}

In other words, at first step, internal factors of system and uncertainty about marketing and managing and human resource risk factors and insecurity in system are considered as the most important factors in failure of system. However in next steps if functional factor is removed, yet subset of security and safety risks are important and have priority. In such a way, collection of external risk factors of system has more influence on level of tourists' satisfaction in destination. Among these external risks, variation in the value of financial risks has significant influence on level of satisfaction. Hsu and Lin (2006) also concluded that the most important risk factor is economic one and affects motivation and demand of tourists in trip.

Therefore noticing to manner of communication, amount of influence among these factors and their changes will affect perspective of tourism industry future and it's possible to forecast how and to what boundary each of the changes attack and hurt trajectory of sustainable tourism development and as long as probabilities of damages and incidents doesn't decline to the lowest level, one cannot expect any development with full confidence. In this study with glancing procedure of accessing and managing risk in the course of developing tourism destination, this axiom can be fortified and acknowledged that forecasting and right and realistic providence in programming and managing tourism activities is necessary. In other words, forecasting the field of probability whether subjective or objective has inevitable importance.

\section{Conclusions}

One of the very important things in systematic planning of tourism is risks assessment and forecasting them so that lack of this field in procedure of tourism planning is one of the most critical reasons to failure of developing tourism. Considering that tourism occur in probable environment, we must assess and forecast it in future perspective in insecure and changing environment, because tourism environment have features that always have been exposed to probabilities and makes the environment and spaces of forming activities almost impossible. The reasons for the impossible spaces are the changes that are forming 
and occurring. So, as long as probability of damages and incidents doesn't reach its lowest level, developing tourism with full confidence cannot be expected. Planning according to forecasting risks is one of the ways that facilitate the field for decreasing probability and implementing right actions. In this study in order to design system, forecasting and measuring value of risk probabilities in tourism destination for maximum usage of current tourists, integrated approach, FIS and DRSA has been used. FIS is one of computational frames of famous conception of fuzzy set and DRSA is one of the ways of discovery knowledge coincident with FIS rule base which is designed as an expert system. For this purpose according to previous studies, components and dimensions of risk in tourism destination as a system - is defined and it is was implemented a system for assessing and forecasting tourism risk. Achieved results from this study portend efficiency and acceptability of this system for forecasting tourism risk. Also integrated method will help this system to be as accurate as possible. Current study as an innovative method in the field of tourism risk, with implementing of inference fuzzy system applying various criteria and components. Secondly, with implementing DRSA for discovering knowledge, planners structurally and with dependence of knowledgebase can fulfill effective risks and pursue management of more unified and optimum risk. Proposed model for designing fuzzy expert system provide the ability for all institutions and planners according to their need and circumstances design and implement their systems.

\section{References}

Assmuth, T.; Hildén, M.; Benighaus, C. 2010. Integrated risk assessment and risk governance as sociopolitical phenomena: a synthetic view of the challenges, Science of the Total Environment 408(18): 3943-3953. http://dx.doi.org/10.1016/j.scitotenv.2009.11.034

Aven, T. 2011. A risk concept applicable for both probabilistic and non-probabilistic perspectives, Safety Science 49(8): 1080-1086. http://dx.doi.org/10.1016/j.ssci.2011.04.017

Baraldi, P.; Librizzi, M.; Zio, E.; Podofillini, L.; Dang, V. N. 2009. Two techniques of sensitivity and uncertainty analysis of fuzzy expert systems, Expert Systems with Applications 36(10): 12461-12471. http://dx.doi.org/10.1016/j.eswa.2009.04.036

Bentley, T. A.; Page, S. J. 2008. A decade of injury monitoring in the New Zealand adventure tourism sector: a summary risk analysis, Tourism Management 29(5): 857-869. http://dx.doi.org/10.1016/j.tourman.2007.10.003

Błaszczyński, J.; Greco, S.; Słowiński, R. 2007. Multi-criteria classification - a new scheme for application of dominance-based decision rules, European Journal of Operational Research 181(3): 1030-1044. http://dx.doi.org/10.1016/j.ejor.2006.03.004

Błaszczyński, J.; Greco, S.; Słowiński, R. 2012. Inductive discovery of laws using monotonic rules, Engineering Applications of Artificial Intelligence 25(2): 284-294. http://dx.doi.org/10.1016/j.engappai.2011.09.003

Butler, R.; Hinch, T. (Eds.). 2007. Tourism and indigenous peoples: issues and implications. Oxford: Elsevier. http://dx.doi.org/10.1016/B978-0-7506-6446-2.50001-6

Eitzinger, C.; Wiedemann, P. 2007. Risk perceptions in the alpine tourist destination Tyrol - an exploratory analysis of residents' views, Tourism Management 28(3): 911-916.

http://dx.doi.org/10.1016/j.tourman.2006.03.011 
Ferreira, F. A.; Marques, C. S.; Reis, M. M.; Ferreira, N. C.; Çipi, A. 2015. Evolutionary patterns and development prospects for e-government: a Delphi-based approach to perceptions of the administrative agent, Journal of Business Economics and Management 16(1): 18-36. http://dx.doi.org/10.3846/16111699.2013.770790

Fuchs, G.; Reichel, A. 2006. Tourist destination risk perception: the case of Israel, Journal of Hospitality \& Leisure Marketing 14(2): 83-108. http://dx.doi.org/10.1300/J150v14n02_06

Fuchs, G.; Reichel, A. 2011. An exploratory inquiry into destination risk perceptions and risk reduction strategies of first time vs. repeat visitors to a highly volatile destination, Tourism Management 32(2): 266-276. http://dx.doi.org/10.1016/j.tourman.2010.01.012

Getz, D. 1986. Models in tourism planning: towards integration of theory and practice, Tourism Management 7(1): 21-32. http://dx.doi.org/10.1016/0261-5177(86)90054-3

Glaesser, D. (Ed.) 2006. Crisis management in the tourism industry. $2^{\text {nd }}$ ed. Oxford: Elsevier. http://dx.doi.org/10.1016/B978-0-7506-6523-0.50001-8

Goeldner, C. R.; Ritchie, J. B. 2009. Tourism: principles, practices, philosophies. $11^{\text {th }}$ ed. John Wiley \& Sons.

Greco, S.; Matarazzo, B.; Slowinski, R. 1999. The use of Rough Sets and Fuzzy Sets in MCDM, International Series in Operations Research \& Management Science 21: 397-455. http://dx.doi.org/10.1007/978-1-4615-5025-9_14

Greco, S.; Matarazzo, B.; Slowinski, R. 2001. Rough Sets Theory for multicriteria decision analysis, European Journal of Operational Research 129(1): 1-47. http://dx.doi.org/10.1016/S0377-2217(00)00167-3

Greco, S.; Matarazzo, B.; Slowinski, R. 2002. Rough approximation by dominance relations, International Journal of Intelligent Systems 17(2): 153-171. http://dx.doi.org/10.1002/int.10014

Greco, S.; Matarazzo, B.; Slowinski, R. 2005. Decision rule approach, in J. Figueira, S. Greco, M. Erghott (Eds.). Multiple criteria decision analysis: state of the art surveys, New York: Springer-Verlag, 507-563. http://dx.doi.org/10.1007/0-387-23081-5_13

Gunn, C. A.; Var, T. 2002. Tourism planning: basics, concepts, cases. $4^{\text {th }}$ ed. New York: Routledge.

Haji, A.; Assadi, M. 2009. Fuzzy expert systems and challenge of new product pricing, Computers \& Industrial Engineering 56(2): 616-630. http://dx.doi.org/10.1016/j.cie.2007.03.005

Hall, C. M. 2007. Tourism planning: policies, processes and relationships. $2^{\text {nd }}$ ed. Essex: Pearson Education.

Hinch, T.; Butler, R. 1996. Indigenous tourism: a common ground for discussion, in Tourism and Indigenous Peoples. London: International Thompson Business Press, 3-21.

Hongxia, L.; Xian, C.; Wei, L. 2012. Analysis on influencing factors of emergency based on system engineering, Systems Engineering Procedia 5: 15-20. http://dx.doi.org/10.1016/j.sepro.2012.04.003

Hsu, T. H.; Lin, L. Z. 2006. Using fuzzy set theoretic techniques to analyze travel risk: an empirical study, Tourism Management 27(5): 968-981. http://dx.doi.org/10.1016/j.tourman.2005.10.022

Inskeep, E. 1991. Tourism planning: an integrated and sustainable development approach. New York: Wiley.

Jafari, J.; Ritchie, J. B. 1981. Toward a framework for tourism education: problems and prospects, Annals of Tourism Research 8(1): 13-34. http://dx.doi.org/10.1016/0160-7383(81)90065-7

Kaspar, C. 1989. Systems approach in tourism: the Saint Gall management model, in S. F. Witt, L. Moutinho (Eds). Tourism marketing and management handbook. Hemel Hempstead: PrenticeHall International, 443-446.

Kaspar, C. 1991. Die tourismuslehre im grundriss. $4^{\text {th }}$ ed. Bern: Paul Haupt Verlag.

Kemp, C. 2009. Event tourism: a strategic methodology for emergency management, Journal of Business Continuity \& Emergency Planning 3(3): 227-240. 
Kennedy, V. 1998. Risk management in the Irish tourism industry: the contribution of a portfolio investment approach, Tourism Management 19(2): 119-126.

http://dx.doi.org/10.1016/S0261-5177(97)00103-9

Law, R. 2006. The perceived impact of risks on travel decisions, International Journal of Tourism Research 8(4): 289-300. http://dx.doi.org/10.1002/jtr.576

Leiper, N. 1979. The framework of tourism: towards a definition of tourism, tourist, and the tourist industry, Annals of Tourism Research 6(4): 390-407. http://dx.doi.org/10.1016/0160-7383(79)90003-3

Lepp, A.; Gibson, H. 2003. Tourist roles, perceived risk and international tourism, Annals of Tourism Research 30(3): 606-624. http://dx.doi.org/10.1016/S0160-7383(03)00024-0

Lin, Y.-Y.; Pan, N.-H. 2014. Multi period performance assessment model for the site property management, International Journal of Strategic Property Management 18(4): 332-343. http://dx.doi.org/10.3846/1648715X.2014.970596

Liu, R.-H.; Zhai, F.-Y. 2008. Model identification of risk management system, in $4^{\text {th }}$ International Conference on Wireless Communications, Networking and Mobile Computing (WiCOM'08), 12-14 October 2008, Dalian, 1-4. http://dx.doi.org/10.1109/WiCom.2008.2430

Maknickienè, N.; Maknickas, A. 2013. Financial market prediction system with Evolino neural network and Delphi method, Journal of Business Economics and Management 14(2): 403-413. http://dx.doi.org/10.3846/16111699.2012.729532

Matthews, C. 2003. A formal specification for a fuzzy expert system, Information and Software Technology 45(7): 419-429. http://dx.doi.org/10.1016/S0950-5849(03)00013-2

Najjaran, H.; Sadiq, R.; Rajani, B. 2006. Fuzzy expert system to assess corrosion of cast/ductile iron pipes from backfill properties, Computer-Aided Civil and Infrastructure Engineering 21(1): 67-77. http://dx.doi.org/10.1111/j.1467-8667.2005.00417.x

Pawlak, Z. 1982. Rough sets, International Journal of Information \& Computer Sciences 11: 341-356. http://dx.doi.org/10.1007/BF01001956

Pawlak, Z. 1991. Rough sets. Theoretical aspects of reasoning about data. Dordrecht: Kluwer Academic Publishers.

Peattie, S.; Clarke, P.; Peattie, K. 2005. Risk and responsibility in tourism: promoting sun-safety, Tourism Management 26(3): 399-408. http://dx.doi.org/10.1016/j.tourman.2003.11.020

Perera, J.; Holsomback, J. E. R. R. Y. 2005. An integrated risk management tool and process, in Aerospace Conference, 5-12 March 2005, Big Sky, MT, 129-136.

http://dx.doi.org/10.1109/AERO.2005.1559306

Pizam, A.; Jeong, G. H.; Reichel, A.; van Boemmel, H.; Lusson, J. M.; Steynberg, L.; Montmany, N. 2004. The relationship between risk-taking, sensation-seeking, and the tourist behavior of young adults: a cross-cultural study, Journal of Travel Research 42(3): 251-260.

http://dx.doi.org/10.1177/0047287503258837

Quintal, V. A.; Lee, J. A.; Soutar, G. N. 2010. Risk, uncertainty and the theory of planned behavior: a tourism example, Tourism Management 31(6): 797-805.

http://dx.doi.org/10.1016/j.tourman.2009.08.006

Razavi Hajiagha, S. H.; Mahdiraji, H. A.; Hashemi, S. S.; Turskis, T. 2015. Determining weights of fuzzy attributes for multiattribute decision-making problems based on consensus of expert opinions, Technological and Economic Development of Economy 21(5): 738-755. http://dx.doi.org/10.3846/20294913.2015.1058301

Ritchie, B. W. 2009. Crisis and disaster management for tourism. Bristol: Channel View Publications.

Sessa, A. 1988. The science of systems for tourism development, Annals of Tourism Research 15(2): 219-235. http://dx.doi.org/10.1016/0160-7383(88)90084-9 
Shen, K. Y.; Tzeng, G. H. 2015. Combining DRSA decision-rules with FCA-based DANP evaluation for financial performance improvements, Technological and Economic Development of Economy (in press). http://dx.doi.org/10.3846/20294913.2015.1071295

Siler, W.; Buckley, J. J. 2005. Fuzzy expert systems and fuzzy reasoning. New Jersey: John Wiley \& Sons.

Simpson, P. M.; Siguaw, J. A. 2008. Perceived travel risks: the traveller perspective and manageability, International Journal of Tourism Research 10(4): 315-327. http://dx.doi.org/10.1002/jtr.664

Słowiński, R.; Greco, S.; Matarazzo, B. 2007. Dominance-based rough set approach to reasoning about ordinal data, in Rough sets and intelligent systems paradigms. Berlin Heidelberg: Springer, 5-11. http://dx.doi.org/10.1007/978-3-540-73451-2_2

Smith, S. L. 1988. Defining tourism a supply-side view, Annals of Tourism Research 15(2): 179-190. http://dx.doi.org/10.1016/0160-7383(88)90081-3

Sönmez, S. F.; Graefe, A. R. 1998. Influence of terrorism risk on foreign tourism decisions, Annals of Tourism Research 25(1): 112-144. http://dx.doi.org/10.1016/S0160-7383(97)00072-8

Spanoudis, C. 1982. Trends in tourism planning and development, Tourism Management 3(4): 314-318. http://dx.doi.org/10.1016/0261-5177(82)90057-7

Susnienè, D.; Purvinis, O. 2015. Empirical insights on understanding stakeholder influence, Journal of Business Economics and Management 16(4): 845-860. http://dx.doi.org/10.3846/16111699.201 3.785974

Tan, Y.; Shen, L.-Y.; Langston, C. 2014. A fuzzy approach for adaptive reuse selection of industrial buildings in Hong Kong, International Journal of Strategic Property Management 18(1): 66-76. http://dx.doi.org/10.3846/1648715X.2013.864718

Tsai, C. H.; Chen, C. W. 2011. The establishment of a rapid natural disaster risk assessment model for the tourism industry, Tourism Management 32(1): 158-171. http://dx.doi.org/10.1016/j.tourman.2010.05.015

Tsaur, S. H.; Tzeng, G. H.; Wang, G. C. 1997. The application of AHP and fuzzy MCDM on the evaluation study of tourist risk, Annals of Tourism Research 24(4): 796-812.

Yates, J. 1992. Risk-taking behavior. Oxford: John Wiley \& Sons.

Ye, X.; Wen, J. 2009. Study on disaster risk management framework in tourist destination, in International Conference on Environmental Science and Information Application Technology (ESIAT 2009), 4-5 July 2009, Wuhan, 3: 182-186. http://dx.doi.org/10.1109/ESIAT.2009.338

Ye, X.; Wen, J.; Ding, P. 2010. Integrated natural disasters risk management in tourism destination - a case study of 5.12 WenChuan Earthquake, in IEEE International Conference on Management of Innovation and Technology (ICMIT 2010), 2-5 June 2010, Singapore, 1248-1252. http://dx.doi.org/10.1109/ICMIT.2010.5492819

Zhiwei, Y.; Zhongyuan, J. 2012. A survey on the evolution of risk evaluation for information systems security, Energy Procedia 17: 1288-1294. http://dx.doi.org/10.1016/j.egypro.2012.02.240 
Hassanali FARAJI SABOKBAR. Associate Professor at the Department of Human Geography, University of Tehran. He is author four GIS and cartography books and publish more than 80 papers in spatial analysis and modeling, and spatial planning. His research interests include desktop, web and mobile GIS developing and develop some software such as SDSS for urban management and LBS in ABFA.

Athareh AYASHI received her MS on tourism planning (2012) and BS in cartography (2008) form the University of Tehran. Her research interests include spatial analysis, decision-making, risk assessment and tourism electronic marketing.

Ali HOSSEINI received his PhD (2015), MS (2011) and BS (2009) degrees in human, geography and urban planning from the University of Tehran. His research interests are concerned with spatial planning, urban planning, multiple criteria decision making and quantitative methods. He has published papers and book chapters in several international and national journals.

Audrius BANAITIS. Professor at the Department of Construction Economics and Property Management of Vilnius Gediminas Technical University. His research interests include project/risk management and project success, property management, sustainability and construction industry development, multiple criteria decision making: applications in construction and real estate.

Nerija BANAITIENE. Associate Professor at the Department of Construction Economics and Property Management of Vilnius Gediminas Technical University. Her research interests include project/risk management, total quality management, building life cycle analysis, multiple criteria decision making: applications in construction and real estate.

Raziyeh AYASHI received her MS in tourism planning (2014) form the Kharazmi University and BS in human geography (2010) form the University of Tehran. Her research interests include sustainable tourism, GIS, electronic tourism and marketing. 